INTERNATIONAL JOURNAL OF SYSTEMATIC BACTERIOLOGY

Vol. 16, No. 4 October 1966 pp. 417-422

\title{
THE STATUS OF THE TERM "DUISBURG" AS THE NAME OF A SALMONELLA SEROTYPE ${ }^{1}$
}

\author{
Macdonald Fulton and A. W. Fulton ${ }^{2}$ \\ Mississippi State College for Women \\ Columbus, Mississippi
}

\begin{abstract}
After reviewing published information on Salmonella gallinarum var. duisburg ( $9:-:-)$, and on $\underline{S} \cdot$ duisburg $(1,4,12,27:$ d:enz: 15$)$, authors caution against the re-use of names that have been discarded for any reason.
\end{abstract}

Int roduction

In the course of assembling the published information regarding the hosts and vectors and the geographical distributions of salmonellas, it became evident that there was confusion in the data accumulating under the heading "duisburg," and it was seen that the term had been applied to two different serotypes. This name was first used by Kauffmann (15) in 1934 as a trivial designation for certain atypical strains of $\underline{\text { S. gallinarum }}(9,12:--:--)$ which had been isolated from human gastroenteritis. Later Kauffmann(17) established the term as the name of a different serotype, 1, 4, 12, 27:d:enz 15 , described in 1954 by Korell and Seeliger (20). Occasionally the record was further confused when duisburg was misspelled as duisberg. In order to define these two bacteria that carry the same name, the histories of both will be briefly reviewed.

\footnotetext{
1 Supported in part by PHS research grant E-2472 and completed under PHS Research Grant TW00148 from the Office of International Research of the National Institutes of Health to Louisiana State University.

2 Former address: Louisiana State University Medical Center, New Orleans, Louisiana.
} 


\section{The Gallinarum-Duisburg Strains}

The cultures that received the trivial name "duisburg strains" were isolated in 1933 by $O$. Müller and Rodenkirchen (21) from human gastroenteritis and from the suspected food vehicle. The characteristics of the strains were reported in the same year by R. Müller (22) and studied further in 1934 by Kauffmann (15), who correctly assessed their systematic

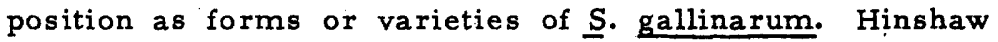
(12) later restudied these same strains. The name was applied by Cloud (7) to a strain isolated from a human infection in 1938. Rutten (24) listed 5 strains of human origin isolated in Curacao, and Gomez Lus ( 11 ) isolated 1 strain from man in 1960. Meanwhile, Clarenburg and Kampelmacher (6) found it twice in chicks, and van Dorssen (26) reported it from 4 outbreaks in chicks. Eliminating duplicates where possible, it appears that 17 strains have been reported, including 11 from man and 6 from chicks. The strains from man were isolated in Europe, the United States, and the West Indies. Strains from chicks were reported from The Netherlands only, where no human infection has yet been described.

\section{The Duisburg Serotype}

The group B serotype now designated as $\underline{S}$. duisburg was first isolated by Korell and Seeliger (20) in 1953 from a child with diarrhea and that strain was listed in a summary of salmonellas from West Germany by Seeliger (25) in 1956.

The discoverers stated the essential features of the antigenic structure and bacteriological characteristics, but applied no name to the serotype, in conformity with the recommendation of the Sixth (Rome) International Congress. The serotype name was published by Kaufmann and Petersen (17) in a list of additional serotypes in 1956. It appeared again in 1957 (18) where the Kauffmann-White Schema and the list of Salmonella serotypes supersedes those in Kauffmann's (16) 1954 book. Subsequently the antigenic formula was amended twice by Kaufmann, after which it appears correctly in his (19) 1961 book, and also in Edwards and Ewing (10). Meanwhile the serotype was isolated in Ghana by Hughes (13), in Nigeria by Collard (8), and in South Africa by Bokkenheuser and Greenberg (3). It was also found in Belgium by Pintelon(23), this being probably the same strain in the list by van Oye and Lafontaine (27). Thus it apparently has been reported 5 times, each time from man, and has 
occurred in northwestern Europe and in both Central and South Africa.

\section{Discussion}

Kauffmann called the original strains of the variety of gallinarum "the Duisburg strains" and showed that they were a biochemical variety that serologically belonged with $\underline{S}$. gallinarum. This serotype in turn was found to be serologically similar to $\underline{S}$. pullorum and the whole complex was first reduced to $\underline{S}$. gallinarum-pullorum by the British Bacteriaceae Subcommittee (4), and eventually to $\underline{S}$. gallinarum by Kalz (14) in the 7th Edition of Bergey's Manual. S. gallinarum var. duisburg is no longer listed in the genus Salmonella because the practice of naming biochemical variants of the salmonella serotypes was discontinued.

The confusion that exists occurred when the term "duisburg," having been left unemployed, was used to designate a new and antigenically entirely distinct serotype. In the International Bacteriological Code (5) Rule 19 of Section 5 did not indicate any disposal to be made of names that would be eliminated when taxa are combined. Nor did Section 6 of the Code indicate specifically that names so eliminatedwere to be considered nomina rejicienda. However, this would appear to be both reasonable and consistent with the intentions implied by the Code.

Guarding discarded names from re-use may have other value besides the avoidance of confusion in taxonomy. For example, further experience may reveal that varietal names are useful in subdividing serotypes that are frequently encountered. Barbesier (1) described gallinarum cultures with differing biochemical properties, and Costin et al. (9) reported a large series of gallinarum strains, falling into several biochemical groups. Serological differences have also been described, in the 0-12 antigen by Blaxland et al. (2) and in the presence of antigen $0-1$ by Edwards and Ewing (10). The complex of bacteria of related but not identical characteristics that is represented by the Bergey name $\underline{S}$. gallinarum may need to be divided for epidemiological reasons, as suggested in the work of Costin et al. (9). In that event, a revival of interest in biochemical varieties may occur. Names would then be useful.

The multiplication of named forms is deplored by bacteriologists. Yet naming helps to conserve information that otherwise might be buried and lost. Consider the result of 
the suppression of the name kunzendorf:-- This form was distinctive biochemically, antigenically, and epidemiologically. However, by a simple laboratory manipulation the naturally-occurring monophasic form could be altered serologically. On this basis the kunzendorf serotype was sunk as a synonym of $\underline{S}$. cholerae suis. The surviving term was made less specific, therefore using it conveys less information. Furthermore, potentially useful epidemiological information is being lost. The argument illustrated by this example applies specifically to the gallinarum-pullorumduisburg complex. Here the oversimplified terminology may conceal differences in the hosts of the members of the complex, and obscure cycles of transmission.

What action might be taken in the duisburg case? Perhaps it would be possible to make definite decisions on two points: First, the present terminology should stand as it is in order to avoid more confusion. Second, a definite agreement should be made that for the future, the name of a taxon that is vacated by the merging or subordinating of that taxon to another joins other kinds of invalid terms on a rejected list and will not be available again without special action to revive it.

\section{References}

1. Barbesier, J. 1957. Sur une variété de Salmonella pullorum. Arch. Inst. Pasteur Algérie 35:382-390.

2. Blaxland, J. D., W. J. Sojka, and A. M. Smither. 1956. A study of Salmonella pullorum and Salmonella gallinarum strains isolated from field outbreaks of disease. Jour. Comp. Pathol. Therp. 66:270-277.

3. Bokkenheuser, V. and M. Greenberg. 1959. A review of salmonellosis in South Africa. S. African Med. Jour. 33:702-706.

4. British Bacteriaceae Subcommittee. 1952. Classification of the Bacteriaceae. Intern. Bull. Bact. Nomen. Taxon. 2:137-140.

5. Buchanan, R.E., R. St. John-Brooks, and R.S. Breed. 1948. International Bacteriological Code of Nomenclature. Jour. Bact. 55:287-306.

6. Clarenburg, A. and E.H. Kampelmacher. 1959. Salmonella-type ringen in 1957 . Verslag. Mededal. Betreff. Volksgezondh. 1959(2):362-368. 
7. Cloud, O.E. 1943. Perforation with peritonitis from Shigella gallinarum (variety of duisberg). Med. Bull. Veterans Adm. 19:335-336.

8. Collard, P. and R. Sen. 1960. Serotypes of Salmonella at Ibadan, Nigeria, with special note of the new serotypes isolated in Nigeria. Jour. Infect. Dis. 106:270275.

9. Costin, I. D., L. Petrica, M. Garoiu, P. Onica, A. Pelle, and N. Dinǔ. 1964. Correlation between the origin and biochemical behaviour of Salmonella gallinarum and Salmonella pullorum cultures. Zentr. Bakteriol., Parasitenk., Abt. I. Orig. 194:342-350.

10. Edwards, P.H. and W.H. Ewing. 1962. Identification of Enterobacteriaceae. 2nd ed. Burgess Publishing Co., Minneapolis.

11. Gomez Lus, R. 1960. Neustra experiencia sobre las salmonelosis humanas en el adulto. Clín. Lab. 69:1721.

12. Hinshaw, W.R. 1941. Cysteine and related compounds for differentiating members of the genus Salmonella. Hilgardia 13:583-621.

13. Hughes, M. H. 1958. Salmonella infections in Accra, Ghana, West Africa. Trans. Roy. Soc. Trop. Med. Hyg. 52:377-382.

14. Kalz, G. 1957. Genus IX. Salmonella Lignières 1900. pp. 368-383. In R.S. Breed, E.G.D. Murray, and N. R. Smith, (ed.). Bergey's Manual of Determinative Bacteriology, 7th ed. Williams and Wilkins Co., Baltimore.

15. Kauffmann, F. 1934. Untersuchungen über die Duisburger Gallinarum-Stamme. Zentr. Bakteriol., Parasitenk., Abt.I. Orig. 132:337-342.

16. Kauffmann, F. 1954. Enterobacteriaceae. 2nd ed. Munksgaard, Copenhagen.

17. and A. Petersen. 1956. The biochemical group and the type differentiation of Enterobacteriaceae by organic acids. Acta Pathol. Microbiol. Scand. 38: $481-491$.

18. 1957. Das Kauffmann-White-Schema (Diagnostisches Salmonella-Antigenschema). Ergeb. Mikrobio1. Immunitätsfors ch. 30:160-216.

19. 1961. Die Bakteriologie der Salmonella-Species. Munksgaard, Copenhagen. 
20. Korell, O. and H. Seeliger. 1954. Ein neuer Typ der Salmonella-B-Gruppe (Salmonella 4, 12:d:e, $n, z_{15}$ ). Zentr. Bakteriol., Parasitenk., Abt. I. Orig. 161: $421-422$.

21. Müller, O. and J. Rodenkirchen. 1933. Ueber Lebensmittellinfektionen durch Bacillus ent. Gaertner in Mülheim-Ruhr 1930-1932. Veroffentl. Geb. Med.Verwalt 39:377-383.

22. Müller, R. 1933. Hühne renteritis - und atypische Gärtne rbakterien bei Gastroenteritiden durch Eierspeisen. Muench. Med. Wschr. 80:1771-1772.

23. Pintelon, J. 1962. Symptômes cliniques dans les salmonelloses de l'enfant. Acta Paediat. Belg. 16: 377-392.

24. Rutten, F.J. 1957. La salmonelosis en Curazao durante el periodo 1948-1954. Bol. Ofic. Sanit. Panam. 43:424-432.

25. Seeliger, H.P.R. 1956. Salmonellosen in Deutschland (1953-1955). Arch. Hyg. Bakteriol. 140:499-528.

26. van Dorssen, G. A. 1950. Cultural variations in some strains isolated from cases of pullorum disease. Tijdschr. Diergeneesk. 75:617-621.

27. van Oye, E. and A. Lafontaine. 1962. Etat actuel du probleme des salmonelloses humaines en Belgique. Arch. Belges Med. Sociale 20:503-514. 